\title{
Lower urinary tract symptoms in rheumatoid arthritis and spondyloarthritis male patients versus controls
}

\author{
ROUACHED LEILA ${ }^{1,3}$, FAZAA ALIA ${ }^{1,3}$, MOURAD DALI KHEREDDINE ${ }^{2,3}$, SAMI BEN RHOUMA $^{2,3}$, \\ MILADI SAOUSSEN ${ }^{1,3}$, OUENNICHE KMAR ${ }^{1,3}$, SOUABNI LEILA $^{1,3}$, KASSAB SELMA $^{1,3}$, \\ CHEKILI SELMA $^{1,3}$, BEN ABDELGHANI KAWTHER ${ }^{1,3}$, NOUIRA YASSINE ${ }^{2,3}$, LAATAR AHMED $^{1,3}$ \\ ${ }^{1}$ Rheumatology department, Mongi Slim Hospital, La Marsa, Tunisia
${ }^{2}$ Urology department, La Rabta, Tunis, Tunisia \\ ${ }^{3}$ Faculty of Medicin, Tunis El Manar University, Tunis, Tunisia
}

\begin{abstract}
Background. We aimed to evaluate the severity of lower urinary tract symptoms (LUTS) in rheumatoid arthritis (RA) and spondyloarthritis (SpA) male patient versus control, then to determine the relation of LUTS with rheumatic diseases (RD) characteristics and with erectile dysfunction (ED).

Methods. We conducted a cross-sectional case control study including 50 men with RA or SpA and 50 healthy controls. LUTS were evaluated by the International Prostate Symptom Score (IPSS). LUTS bother was evaluated by the Quality of life (QoL) score, which ranges from 0 to 6 . LUTS bother was considered if QoL score exceeded 2. Moreover, erectile function was assessed by the International Index of Erectile Function-5 (IIEF5) (ED if score $<21$ ).

Results. LUTS were significantly more severe in RD patients than controls $(p=0.03)$. However, there was no difference between the two groups in LUTS bother $(\mathrm{QoL})(\mathrm{p}=0.2)$. Comparing RA and SpA showed no difference as to the severity of LUTS or effect of bother on QoL $(\mathrm{p}=0.13, \mathrm{p}=0.5)$. The prevalence of ED in RD patients was not significantly higher than controls $(80 \%$ versus $70 \% ; p=0.2)$. There were also no differences either between RA and SpA groups $(\mathrm{p}=0.74)$.

The severity of LUTS for patients with RD (RA and SpA) was significantly associated with age $(p=0.001)$, age at disease onset $(p=0.002)$ and $\operatorname{ED}(p=0.008)$.

Conclusion. According to our study, men with RD seem to be exposed to more severe LUTS than controls. Also, the severity of LUTS was associated with ED, age of patients and the age of disease onset.
\end{abstract}

Key words: rheumatoid arthritis, spondylarthritis, lower urinary tract symptoms, erectile dysfunction, inflammation.

\section{What is new? What is important?}

- Lower urinary tract symptoms (LUTS) are significantly more severe in males with rheumatic diseases (RD)

- There is no difference between RD group and controls in the impact of LUTS on the quality of life $(\mathrm{QoL})$

- The prevalence of erectile dysfunction (ED) is not significantly more frequent in rheumatic disease $(\mathrm{RD})$ patients than in controls

- The comparison of RA and SpA showed no difference in the severity of LUTS or in the impact of symptom bother on QoL

\section{INTRODUCTION}

Lower urinary tract symptoms (LUTS) are symptoms involving bladder, urinary sphincter, urethra and, in men, the prostate. LUTS may be caused not only by benign or malignant urological diseases but also by diseases entirely independent from urology like rheumatic diseases (RD) [1], systemic sclerosis [2] or Parkinson [3].
Spondyloarthritis (SpA) and rheumatoid arthritis (RA) are chronic rheumatic diseases, characterized by an inflammatory disorder that can lead to serious urogenital diseases with a high risk of urolithiasis, interstitial cystitis, bacterial urogenital infections and increased prevalence of erectile dysfunction (ED) in men [1]. However, LUTS problems are often ignored and few studies are reported about the influence of factors such as inflammation, disease 
activity and treatments on the lower urinary tract of male patients with RA and SpA.

The first aim of this study was to evaluate the severity of lower urinary tract symptoms (LUTS) in RA and SpA male patient versus control and the second was to determine the relation of LUTS with RD characteristics and with ED.

\section{MATERIAL AND METHODS}

\section{Study design}

We conducted a cross-sectional case control study of 50 men with a RD in the form of RA according to the American College of Rheumatology/ European League Against Rheumatism 2010 classification criteria [4] or SpA fulfilling Assessment of Spondyloarthritis Society (ASAS) criteria [5]. The controls included 50 age-matched healthy men. Subjects were eligible for this study if they were sexually active. Patients were excluded if they were on drugs that can cause urinary symptoms or erectile problem, had anatomical defects of penis, had any neurological involvement, vascular disease (hypertension, heart disease, hyperlipidemia) or psychological disorders.

All subjects were informed and gave consent. The ethical committee of Mongi Slim Hospital gave the approval of the work in accordance to the national guidelines (number 20/19).

\section{Data collection}

For each patient and control, age, comorbidities (diabetes mellitus) and habits (smoking) were collected.

For RA and SpA patients, disease duration and age of diagnosis were collected. Disease activity was evaluated based on the level of erythrocyte sedimentation rate $(\mathrm{ESR})(\mathrm{mm} / \mathrm{H} 1)$ and $\mathrm{C}$ Reactive protein $(\mathrm{CRP})(\mathrm{mg} / \mathrm{l})$. It was also evaluated by the Disease Activity Score (DAS28 ESR) in RA patients [6]. In SpA patients, the disease activity was assessed by the Ankylosing Spondylitis Disease Activity Score (ASDAS CRP) and the Bath Ankylosing Spondylitis Disease Activity Index (BASDAI) [7]. The Bath Ankylosing Spondylitis Functional (BASFI) was used to evaluate the functional disability in $\mathrm{SpA}$ patients [7].

Patients' treatments were assessed: non-steroidal anti-inflammatory drug (NSAIDs), conventional synthetic Disease Modifying Anti-Rheumatic Drugs (csDMARDs) and biologic DMARDs (bDMARDs).

\section{Assessment of lower urinary tract symptoms}

The evaluation of urinary symptoms for male patients and controls was based on the International Prostate Symptom Score (IPSS), a validated questionnaire assessing disease severity. It is based on seven questions concerning urinary symptoms and one question concerning quality of life (QoL). Each of the seven questions included six answers indicating increasing severity of the urinary symptom. A score from zero to five is assigned to each answer. The total score can range from zero to thirty five (asymptomatic to very symptomatic). It categorizes symptoms as mild (score $\leq 7$ ), moderate (score from 8 to 19 ) or severe (score from 20 to 35 ).

For the QoL question, also called "Bother question", it evaluates the impact of benign prostatic hyperplasia (BPH) symptoms on QoL. The answer ranges from delighted to terrible (0 to 6). LUTS bother was considered if the QoL question score exceeded 2 .

\section{Assessment of erectile function}

The assessment of erectile function was based on the International Index of Erectile Function-5 (IIEF5). It is a self-reported questionnaire assessing the erectile function for the last six months.

The global score is obtained by adding the scores of five questions. It ranges from 5 to 25 . The identification of ED is considered if the score was below 21 .

\section{Statistical analysis}

Data were analyzed using SPSS software package version 11.5 and reported as means with standard deviations (SD), or as medians with interquartile ranges (IQR).

The Pearson Test was used for the correlation between two quantitative variables and the chi2 test between two qualitative variables. Student's test was used to compare between two means when the sample is normally distributed. Mann Whitney test was used to compare means of non-parametric data. The significance level was set at 0.05 .

Linear logistic regression with "backward elimination" model was used to evaluate factors independently associated with the severity of LUTS. Significant factors $(\mathrm{p}<0.05)$ and factors with $\mathrm{p}$ between 0.05 and 0.15 were included. Results were presented as beta coefficient $(\beta)$ with a confidence interval (CI) of $95 \%$. 


\section{RESULTS}

A. Characteristics of patients and controls

No significant differences have been found between RD group and controls (Table 1) and also between RA and SpA patients (Table 2).

\section{and RA)}

\section{B. Rheumatic disease characteristics (SpA}

Patients with RA had a mean disease duration of $7.1 \pm 6.2$ years and the age at disease onset was $42.9 \pm 16.3$ years. Mean disease activity was mild (DAS28 ESR $=2.28 \pm 1.2$ ). $84 \%$ of patients were on csDMARDs and $23 \%$ on bDMARDs.

Patients with SpA had a mean disease duration was $11.4 \pm 7.1$ years. Mean BASDAI, ASDAS CRP and BAFSI were respectively $2.5 \pm 2.5,2.3 \pm 1.05$ and $2.5 \pm 2.5$. Most of patients $(90 \%)$ were on NSAIDs or csDMARDs and $56.7 \%$ were on bDMARDs.

There was no significant difference in inflammation parameters between RA and SpA groups: CRP $(p=0.59)$ and ESR $(p=0.06)$.

\section{Evaluation of LUTS and LUTS QoL in patients with RD and controls \\ - Comparison of LUTS and LUTS QoL between RD patients and controls: \\ All patients accepted to complete the questionnaire. A significant difference was found}

between the two groups in the severity of LUTS $(\mathrm{p}=0.03)$, yet with no difference in LUTS QoL (bother question) $(\mathrm{p}=0.2)$ (Table 3$)$.

- Comparison of LUTS and LUTS QoL between RA and SpA patients

No significant differences appeared between RA and SpA groups either in the severity of LUTS, or in its impact on the QoL (Table 4).

\section{Evaluation of the erectile function in patients with RD and controls}

The prevalence of male ED in RD group was $80 \%$ versus $70 \%$ in controls $(\mathrm{p}=0.2)$. Moreover, no significant differences between RA and SpA groups were found $(\mathrm{p}=0.74)$.

\section{E. Parameters associated with LUTS in males with RD}

The comparison of patients according to the severity of LUTS in the RD population is illustrated in Table 5. There was a significant difference between the groups in patients' age, age at disease onset and ED (Table 5).

On linear regression analysis, only age and erectile dysfunction were independently associated with the severity of LUTS $(\beta=0.3, p=0.007$ and $\beta=-0.2, p=0.06$ respectively).

Table 1

Characteristics of patients with RD and controls

\begin{tabular}{|l|c|c|c|}
\hline \multicolumn{1}{|c|}{ Parameters } & RD group $(\mathbf{n}=\mathbf{5 0})$ & Controls $(\mathbf{n}=\mathbf{5 0})$ & p \\
\hline Age, mean \pm SD & $44.3 \pm 12.1$ & $48.8 \pm 13.9$ & 0.11 \\
\hline Diabetes mellitus, $\mathbf{n}(\%)$ & $4(8)$ & $14(28)$ & 0.09 \\
\hline Smoking, $\mathbf{n}(\%)$ & $20(40)$ & $29(58)$ & 0.714 \\
\hline
\end{tabular}

RD: rheumatic disease, SD: standard deviation

Table 2

Comparison of characteristics of RA and SpA patients

\begin{tabular}{|l|c|c|c|}
\hline \multicolumn{1}{|c|}{ Parameters } & RA patients $(\mathbf{n}=\mathbf{1 3})$ & SpA patients $(\mathbf{n}=\mathbf{3 7})$ & $\mathbf{p}$ \\
\hline Age, mean $\mathbf{\text { SD }}$ & $49.6 \pm 12.8$ & $42.5 \pm 11.4$ & 0.06 \\
\hline Diabetes mellitus, $\mathbf{n}(\%)$ & $1(17)$ & $3(8)$ & 0.96 \\
\hline Smoking, $\mathbf{n}(\%)$ & $5(38.4)$ & $15(40.5)$ & 0.58 \\
\hline
\end{tabular}

RA: rheumatoid arthritis, SpA: spondyloarthritis, SD: standard deviation

Table 3

Comparison of LUTS and LUTS QoL in patients with RD and controls

\begin{tabular}{|l|c|c|c|}
\hline \multicolumn{1}{|c|}{ Parameters } & RD group (n= 50) & Controls $(\mathbf{n}=\mathbf{5 0})$ & p \\
\hline Severity of LUTS & & & \\
-Mild, n (\%) & $\mathbf{3 2}(\mathbf{6 4})$ & $\mathbf{3 8}(\mathbf{7 6})$ & \\
-Moderate, $\mathbf{n}(\mathbf{\%})$ & $\mathbf{1 2}(\mathbf{2 4})$ & $\mathbf{1 2}(\mathbf{2 4})$ & $\mathbf{0 . 0 3}$ \\
-Severe, $\mathbf{n}(\%)$ & $\mathbf{6 ( 1 2 )}$ & $\mathbf{0}(\mathbf{0})$ & \\
\hline LUTS QoL (IPSS > 2) & $12(24)$ & $7(14)$ & 0.2 \\
\hline
\end{tabular}

RD: rheumatic disease, SD: standard deviation, LUTS: Lower urinary tract symptoms: QoL: quality of life 
Table 4

Comparison of LUTS and LUTS QoL in patients with RA and SpA

\begin{tabular}{|l|c|c|c|}
\hline \multicolumn{1}{|c|}{ Parameters } & RA patients $(\mathbf{n}=\mathbf{1 3})$ & SpA patients $(\mathbf{n}=\mathbf{3 7})$ & $\mathbf{p}$ \\
\hline Severity of LUTS & & & \\
- Mild, $\mathbf{n}(\%)$ & $8(62)$ & $24(64.8)$ & \\
- Moderate, $\mathbf{n}(\%)$ & $2(15)$ & $10(27)$ & 0.3 \\
- Severe, $\mathbf{n}(\%)$ & $3(23)$ & $3(8.2)$ & \\
\hline LUTS QoL(IPSS $>$ 2) (n) & $4(30.7)$ & $8(21.6)$ & 0.5 \\
\hline
\end{tabular}

Significant at $\mathrm{p}<0.05 ; \mathrm{SpA}$ : spondylarthritis; IPSS: International Prostate Symptom Score; LUTS: lower urinary tract symptoms; IIEF: the International Index of Erectile Function, QoL: quality of life

Table 5

Parameters linked to the severity of LUTS in males with RD

\begin{tabular}{|c|c|c|c|c|}
\hline & $\begin{array}{l}\text { Mild LUTS } \\
\quad(\mathrm{n}=\mathbf{3 2})\end{array}$ & $\begin{array}{l}\text { Moderate LUTS } \\
\quad(n=12)\end{array}$ & $\begin{array}{l}\text { Severe LUTS } \\
\quad(n=6)\end{array}$ & p \\
\hline Age (mean \pm SD) & $40.2 \pm 11.5$ & $48.6 \pm 10.8$ & $57.6 \pm 10.8$ & 0.001 \\
\hline Diabetes mellitus, n (\%) & $2(11.1)$ & $1(8.3)$ & $1(16.6)$ & 0.6 \\
\hline Smoking, n (\%) & $13(40.6)$ & $5(41.6)$ & $1(16.6)$ & 0.6 \\
\hline Age at disease onset (mean \pm SD) & $30.6 \pm 12.2$ & $40.4 \pm 14.4$ & $49.3 \pm 9.5$ & 0.004 \\
\hline Mean disease duration (years \pm SD) & $10.2 \pm 6.8$ & $11.7 \pm 7.9$ & $9.1 \pm 6.9$ & 0.78 \\
\hline \multicolumn{5}{|l|}{ Disease activity for SPA patients $(\mathrm{n}=37)$} \\
\hline BASDAI (mean \pm SD) & $2.5 \pm 1.8$ & $3 \pm 2.4$ & $1.8 \pm 1.7$ & 0.8 \\
\hline $\operatorname{ASDASCRP}($ mean \pm SD) & $2.2 \pm 1$ & $2.7 \pm 1.2$ & 2.5 & 0.4 \\
\hline \multicolumn{5}{|l|}{ Disease activity for RA patients $(n=13)$ : } \\
\hline DAS28ESR $($ mean \pm SD) & $3.1 \pm 1.2$ & $2.9 \pm 0.5$ & 1.54 & 0.2 \\
\hline CRP $(\mathrm{mg} / \mathrm{L})($ mean $\pm \mathrm{SD})$ & $16.7 \pm 19.7$ & $32.7 \pm 35.1$ & $3.7 \pm 1.8$ & 0.2 \\
\hline $\operatorname{ESR}(\mathbf{m m} / \mathbf{H 1})(\operatorname{mean} \pm \mathrm{SD})$ & $29.7 \pm 20.6$ & $37.3 \pm 35.3$ & $20.5 \pm 8.5$ & 0.8 \\
\hline BASFI $($ mean \pm SD) $)$ for SPA patients $(n=37)$ & $2.7 \pm 2.6$ & $2.9 \pm 2.9$ & $1.3 \pm 0.3$ & 0.6 \\
\hline NSAIDs, $n(\%)$ & $11(34.3)$ & $3(25)$ & $3(50)$ & 0.6 \\
\hline csDMARDs, n (\%) & $16(50)$ & $7(58.3)$ & $3(50)$ & 0.1 \\
\hline bDMARDs, n (\%) & $14(43.7)$ & $8(66.6)$ & $2(33.3)$ & 0.18 \\
\hline $\begin{array}{l}\text { Erectile function } \\
\text { - Normal, n (\%) } \\
\text { - ED, n (\%) }\end{array}$ & $\begin{array}{l}10(31.2) \\
22(68.7)\end{array}$ & $\begin{array}{c}0(0) \\
12(100)\end{array}$ & $\begin{array}{c}0(0) \\
6(100)\end{array}$ & $\mathbf{0 . 0 3}$ \\
\hline
\end{tabular}

SPA: spondyloarthritis; RA: rheumatoid arthritis; LUTS: lower urinary tract symptoms; BASFI; Bath Ankylosing Spondylitis Functional Index; BASDAI: Bath Ankylosing Spondylitis Disease; ASDAS: Ankylosing Spondylitis Disease Activity Score, NSAIDs: non-steroidalanti-inflammatory drug; DMARD: disease modifying anti rheumatic drug; ESR: erythrocyte sedimentation rate, CRP: C-reactive protein; DAS28: Disease Activity Score in 28 joints.

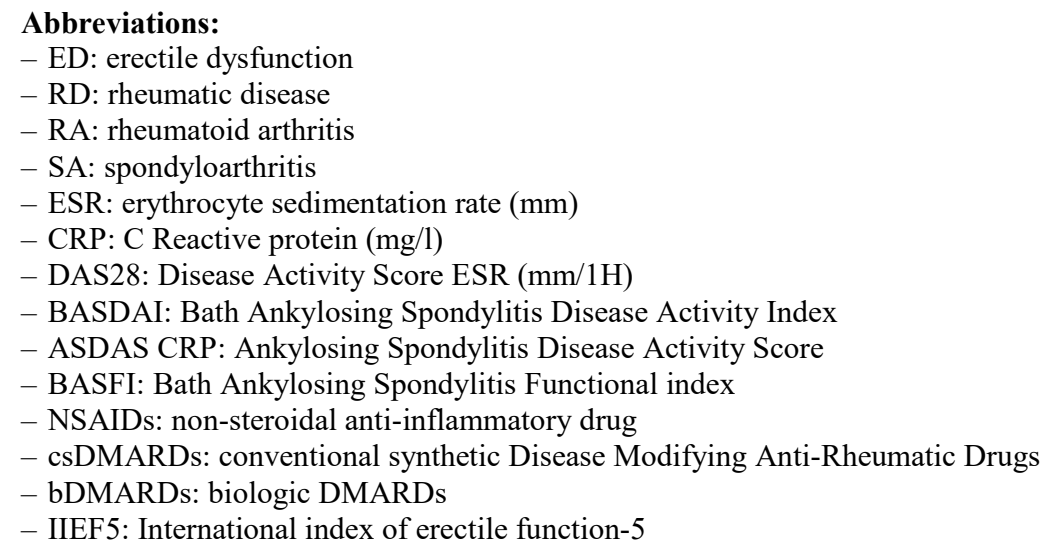

\section{DISCUSSION}

LUTS is a group of clinical symptoms involving bladder, urinary sphincter, urethra and, in men, the prostate. Benign or malignant urological diseases may cause LUTS but also diseases that are entirely independent from urology such as inflammatory musculoskeletal diseases and systemic sclerosis [2]. 
Our study is the first to evaluate simultaneously the severity of LUTS in SpA and RA males, using a standard questionnaire (IPSS), and to compare it with controls.

In our study, the prevalence of moderate to severe LUTS in RD group and controls was respectively $36 \%$ and $24 \%$. We found a significant difference in the severity of LUTS between RD groups and matched controls $(p=0.02)$. However, there was no difference between the two groups in the impact of LUTS on the QoL $(p=0.2)$. Likewise, according to a literature review of urological comorbidities in patients with RA, acute urinary retention is more common in chronic inflammatory musculoskeletal diseases like RA [1]. Some epidemiological studies have also shown that inflammatory rheumatic diseases are associated with increased risk of residual urine and acute urine retention (AUR) [8]. Moreover, a Finnish study by J. Koskima et al. found that arthritis was associated with LUTS [3]. However, in an Indian study, Dahak et al. observed that severe LUTS and LUTS QoL were not different between a SpA group and controls and that LUTS does not appear to be a significant issue [9]. Therefore, a routine assessment of urinary symptoms in SpA patients is not deemed necessary [9].

LUTS were reported in more frequently in woman with other rheumatic diseases, such as fibromyalgia (FM) and Systemic Lupus Erythematous and Sjögren Syndrome (SS) but rarely in men with RA and SpA. De Carvalho Fusco et al. reported that women with FM had worse perineal function, frequent LUTS, and presented more urinary infections, which may impacts negatively on QoL [10]. Moreover, Jones et al. suggested that we should include the evaluation and treatment of urinary symptoms in FM management. Urinary symptoms seem to be associated with more severe FM symptoms [11]. Lee KL et al. reported similar urinary complaints between RA patients and controls [12]. However, those with secondary SS have a more sever LUTS. This finding is similar to the findings observed in patients with primary SS [12].

The reason for the association between RD and LUTS is unknown. The first explanation might be inflammation. H. Tarhan et al. demonstrated that inflammation (CRP level) was higher in patients with LUTS than controls. Besides, CRP levels significantly increased when frequency and urge incontinence scores are higher [13]. However, in our study, we did not find an association between inflammation parameters (CRP and ESR) and the presence of LUTS.

Secondly, men suffering from RD are often over-medicated and this could suggest that LUTS is influenced by the use of immunomodulating drugs [1]. A systematic Review and Meta-Analysis of Randomized Controlled Trial proved that NSAIDs can improve urinary symptoms and flow measures [14]. However, in our study, NSAIDs, csDMARDs and bDMARDs were not associated with the severity of LUTS.

Thirdly, patients with RD are less able to go to the toilet and therefore may have more problematic urinary symptoms than men without RD [3].

In our study, the age of patients, the age of RD diagnosis and the ED significantly increased according to the severity of LUTS among men with $\mathrm{RD}$, suggesting that decreased general health and late diagnosis have an impact on lower urinary tract function. Also, the severity of LUTS is possibly a factor of ED. In line with our study, results of several large-scale studies have shown a significant association between LUTS and ED. A study of 2,476 Spanish men aged from 25 to 70 years with a prevalence of ED between $12 \%$ and $19 \%$, indicated LUTS and RD as risk factors for ED [15].

Moreover, data from the National Health and Social Life Survey (NHSLS) of adults aged from 18 to 59 years indicated that LUTS was a significant predictor for ED [16]. Furthermore, Rosen et al. demonstrated that men with moderateto-severe LUTS in patients with benign prostatic hyperplasia (BPH) have a higher risk for sexual dysfunction, ejaculatory dysfunction, and hypoactive desire. It appears that the mechanisms of LUTS may have an impact on both the erection and ejaculation components of the sexual activity [17].

In another study, a covariance analysis controlling for age and other comorbidities showed that LUTS severity, as determined by IPSS score, was a highly significant predictor of all IIEF domain scores: Erectile function $(\mathrm{R}=0.214 ; \mathrm{p}<0.001)$, intercourse satisfaction $(R=0.120 ; p<0.001)$, orgasmic function $(\mathrm{R}=0.187 ; \mathrm{p}<0.001)$, sexual desire $(\mathrm{R}=0.149 ; \mathrm{p}<0.001)$, and overall satisfaction $(\mathrm{R}=0.138 ; \mathrm{p}<0.001)[18]$.

Concerning the ED, only few studies with a limited number of participants were made in SpA and RA male patients. In our study, there was no significant difference between the RD group and controls in ED prevalence. However, Pirildar et al. reported in a study of $65 \mathrm{SpA}$ male patients that 
erectile function was the most affected domain [19].

More importantly, no comparative study between SpA and RA on LUTS and erectile function was found in literature. In our study, there was no difference between the RA and SpA groups in LUTS severity, presence of LUTS bother and ED prevalence.

It should be noted that our study has some limitations given its monocentric nature with a limited sample size. The results can therefore not be generalized to the rest of the population. Another limitation is the lack of urogenital examination, ultrasonography exploration and urodynamic evaluation. Moreover, we did not exclude smoker and diabetics. However, both rheumatic disease group and control group were similar concerning diabetes and smoking. Besides, these parameters were not significantly associated with LUTS.

\section{CONCLUSIONS}

In the light of the present study, LUTS seems to be more severe in men with RD than in the general population. It is also associated with patient's age, age at disease onset and ED. Future longitudinal studies are needed to observe the effect of RD on urinary symptoms and erectile function.

Introducere. Scopul studiului a fost de a evalua severitatea simptomelor tractului urinar inferior (LUTS) la pacienții de sex masculin cu artrită reumatoidă (RA) și spodilartropatii (SpA), comparativ cu un lot martor și de a determina relația LUTS cu caracteristicile bolii reumatice și disfuncția erectilă.

Metode. A fost realizat un studiu transversal ce a inclus 50 de pacienți cu RA sau SpA şi 50 de martori sănătoși. LUTS au fost evaluate folosind un scorInternational Prostate Symptom Score (IPSS). A fost evaluată și calitatea vieții (QoL). Disfuncția erectilă (ED) a fost evaluată folosind International Index of Erectile Function-5 (IIEF5). Pentru un scor sub 21 s-a pus diagnosticul de ED.

Discutii. LUTS au fost mai severe la pacienții cu patologie reumatică, comparativ cu martorii. Nu au fost diferențe intre cele două grupuri referitor la afectarea $Q o L$. Comparativ, intre $R A$ și $S p$ nu au fost diferențe semnificative privind afectarea QoL. Prevalența ED a fost similară la pacienții cu boli reumatismale și martorii sănătoși. Similar, nu au existat diferențe privind prevalența ED la pacienții din grupul RA și SpA. Severitatea LUTS la pacienții cu RA și SpA s-a asociat cu vârsta $(p=0,001)$, vârsta de debut a patologiei reumatice $(p=0,002)$ și $E D(p=0,008)$.

Concluzii. Pacienții cu boli rerumatice par să fie expuși la LUTS mai severe decât martorii sănătoși. Severitatea LUTS s-a asociat cu ED, vârsta pacienților și vârsta de debut a patologiei reumatice.

Correspondence to: Rouached Leila MD, Rheumatology department, Mongi Slim Hospital, La Marsa, Tunisia, Faculty of Medicine de Tunis, Tunis El Manar University, Tunis, Tunisia.

Tel: 0021621482262.

E-mail: leila_rouached@hotmail.com

Funding: This research received no grant from any funding agency in the public, commercial or non-profit sectors.

Conflict of interest disclosure: None declared.

Ethics approval: The local committee approved the study before any data were collected. All applicable national guidelines were followed (number 20/19).

Consent to participate: Informed consent was obtained from all participants included in the study.

Availability of data and material: Data and material are available.

Acknowledgments: We thank the department of rheumatology and urology for assistance.

Author contribution statement: All authors approved the final manuscript as submitted and agree to be accountable for all aspects of the work. 


\section{REFERENCES}

1. FRIEDL A, MUSTAK M, HÖLTL W, ERLACHER L. Urologische Begleiterkrankungenbei Patientenmitrheumatoider Arthritis: Literaturübersicht. Z FürRheumatol. 2013; 72:910-5.

2. SANCHEZ K, DENYS P, GIULIANO F, PALAZZO C, BÉREZNÉ A, ABID H, et al. Systemic sclerosis: Sexual dysfunction and lower urinary tract symptoms in 73 patients. PresseMédicale. 2016; 45:e79-89.

3. KOSKIMÄKI, M. HAKAMA, H. HUHTALA, T J. Association of Non-urological Diseases with Lower Urinary Tract Symptoms. Scand J UrolNephrol. 2001; 35:377-81.

4. ALETAHA, D., T. NEOGI, et al. 2010 rheumatoid arthritis classification criteria: an American College of Rheumatology/European League Against Rheumatism collaborative initiative. Ann Rheum Dis. 2010. 69(9): 1580-8.

5. RUDWALEIT M, VAN DER HEIJDE D, LANDEWE R, AKKOC N, BRANDT J, CHOU CT, et al. The Assessment of Spondyloarthritis international Society classification criteria for peripheral spondyloarthritis and for spondyloarthritis in general. Ann Rheum Dis. 2011; 70:25-31.

6. VAN GESTEL A M, PREVOO M L, VAN HOF M A, VAN RIJSWIJK M H, VAN DE PUTTE L B, VAN RIEL P L. Development and validation of the European League Against Rheumatism response criteria for rheumatoid arthritis. Comparison with the preliminary American College of Rheumatology and the World Health Organization/International League Against Rheumatism Criteria. Arthritis Rheum. 1996. 39(1): 34-40.

7. WENDLING D, LUKAS C, PACCOU J, et al. Recommendations of the French Society for Rheumatology (SFR) on the everyday management of patients with spondyloarthritis. Joint Bone Spine. 2014. 81(1):6-14.

8. NIAZY M, GABER W, MOGHAZY A, SALEM HK Urological comorbidities in Egyptian rheumatoid arthritis patients: Risk factors and relation to disease activity and functional status. Egypt Rheumatol. 2017; 39:213-6.

9. DHAKA U, SINGH B, DAS S, WAKHLU A, KUMAR P, SRIVASTAVA D, et al Sexual dysfunctions and lower urinary tract symptoms in ankylosing spondylitis. Int J Rheum Dis. 2015; 18.

10. FUSCO HCS DE C, PONTES FILHO MAG, HADDAD JM, ZANETTI MRD, MARQUES AP, FERREIRA EAG. Lower urinary tract symptoms and perineal function in women with and without fibromyalgia: a cross-sectional study. Clin Rheumatol. 2019. 38:2885-90.

11. JONES KD, MAXWELL C, MIST SD, KING V, DENMAN MA, GREGORY WT Pelvic Floor and Urinary Distress in Women with Fibromyalgia. Pain ManagNurs. 2015; 16:834-40.

12. LEE K-L, CHEN M-Y, YEH J-H, HUANG S-W, TAI H-C, YU H-J. Lower urinary tract symptoms in female patients with rheumatoid arthritis. Scand J Rheumatol. 2006; 35:96-101.

13. TARHAN H, EKIN RG, CAN E, CAKMAK O, YAVASCAN O, MUTLUBASOZSAN F, et al C-reactive protein levels in girls with lower urinary tract symptoms. J PediatrUrol. 2016; 12:105.e1-105.e4.

14. KAHOKEHR A, VATHER R, NIXON A, HILL AG. Non-steroidal anti-inflammatory drugs for lower urinary tract symptoms in benign prostatic hyperplasia: systematic review and meta-analysis of randomized controlled trials. BJU Int. 2013; 111:304-11.

15. MARTIN-MORALES A, SANCHEZ-CRUZ JJ, SAENZ DE TEJADA I, RODRIGUEZ- VELA L, JIMENEZ-CRUZ JF, BURGOS-RODRIGUEZ R. Prevalence and independent risk factors for erectile dysfunction in Spain: results of the Epidemiologia de la Disfuncion Erectil Masculina Study. J Urol. 2001; 166:569-74 discussion 574-5.

16. LAUMANN EO, PAIK A, ROSEN RC. Sexual dysfunction in the United States: prevalence and predictors. JAMA. 1999; 281:537-44.

17. ROSEN RC, GIULIANO F, CARSON CC. Sexual Dysfunction and Lower Urinary Tract Symptoms (LUTS) Associated with Benign Prostatic Hyperplasia (BPH). EurUrol. 2005; 47:824-37.

18. ROSEN R, ALTWEIN J, BOYLE P, et al. Lower urinary tract symptoms and male sexual dysfunction: the multinational survey of the aging male (MSAM-7). EurUrol. 2003; 44:637-49.

19. PIRILDAR T, MÜEZZINOĞLU T, PIRILDAR S Sexual function in ankylosing spondylitis: a study of 65 men. J Urol. 2004 ; 171:1598-600.

Received $1^{\text {st }}$ August 2020 